\title{
半円柱周りの空力騒音と流れ構造に関する実験的研究 Experimental Study on Aerodynamic Sound and Flow Structure around a Semi-Circular Cylinder
}

\author{
○正 小熊 靖之（新潟大院） \\ 正 山縣 貴幸（新潟大） \\ 正 藤澤 延行 (新潟大)
}

Yasuyuki OGUMA, Graduate School of Science and Technology, Niigata University, Ikarashi 2-no-cho, Nishi-ku, Niigata

Takayuki YAMAGATA, Visualization Research Center, Niigata University

Nobuyuki FUJISAWA, Visualization Research Center, Niigata University

Key Words: Semi-circular cylinder, PIV, POD, Aerodynamic sound

\section{1. 緒言}

近年, 自動車の低燃費化および低環境負荷の実現のため, ハイブリッド車や電気自動車の割合が増加している。その ため, 空力騒音の相対的重要性は増加している.この空力 騒音源の一つとしてドアミラーから放出される騒音が注目 されており, 車内環境の向上にはその低減が望まれている. ドアミラーのような曲率を持つ複雑な形状の物体に対して 空力騒音の研究は過去になされていない. Fujita ${ }^{(1)}$ は, 半 円柱と角柱を組み合わせた物体において空力騒音の低下を 示唆したが，その低減のメカニズムについては触れていな い. 一方, 空力騒音の発生を考察するには, PIV による流 れ場の計測が有力な手段を提供する. 過去の研究としては, 対称翼からの離散周波数騒音を対象とした研究 ${ }^{(2)}$, 送風機 翼を対象とした研究 ${ }^{(3)}$, 円柱の音源探査研究 ${ }^{(4)}$ が報告され ている。一方，流れ場の構造を理解する統計的手法に POD 解析 ${ }^{(5)}$ がある. Oudheusden et al. ${ }^{\left({ }^{(6)}\right.}$ によると, 角柱周り の速度場を PIV 計測し, 得られた速度場を POD 解析による 速度場の再構成によって位相平均速度場を評価した。 その 結果，周期的な流れ場の場合では低次モードの速度場のみ で任意の位相平均速度場を再構築できることを示した。

本研究では, 半円柱周りの空力騷音の低減メカニズムの 解明を目的として, 半円柱ならびに円柱から放出される騒 音の計測を行う。また, 半円柱, 円柱後流の速度場を PIV によって計測し, さらにPOD 解析を導入することで流れ構 造の変化と騒音特性との関係を明らかにする.

\section{2. 実験および解析方法}

\section{1 実験方法}

半円柱ならびに円柱後流の PIV 計測は低騒音風洞と無響 音室を用いて実施した. 実験装置の詳細は, 文献 ${ }^{(2)} に$ 示す.

Fig. 1 は騷音計測およびPIV 計測における計測部の概略図 である. 本研究では, 直径 $d=15 \mathrm{~mm}$, スパン方向の長さ $l=$ $190 \mathrm{~mm}$ の半円柱ならびに円柱を使用し, アスペクト比は 12.7 である. 計測部の寸法は，断面が $190 \mathrm{~mm} \times 190 \mathrm{~mm}$, 長さは $500 \mathrm{~mm}$ であり, 円柱は測定部入口の下流 $250 \mathrm{~mm}$ の 位置に設置した。実験の平均流速は， $U_{0}=30 \mathrm{~m} / \mathrm{s}$ であり， レイノルズ数は $\operatorname{Re}\left(=U_{0} d / v\right)=3.0 \times 10^{4}$ である（ $v$ ：動 粘度）。瞬時速度場の計測には 2 次元 PIV 法を用いた。 そ の計測システムは, Nd:YAG レーザー $(40-80 \mathrm{~mJ} / \mathrm{pulse})$, CCD カメラ (1280x1024pixels, 12bit)，パルスコントロー ラーからなる標準システムである。トレーサーとしては風 洞上流側で供給したスモーク（直径 $1 \mu \mathrm{m}$ 程度）を用いた。 なお，速度場の計測範囲は，半円柱，円柱の幅方向中央部 付近の後流 $52 \mathrm{~mm} \times 42 \mathrm{~mm}$ とした.また, CCD カメラのフ レームレートは $4 \mathrm{~Hz} て ゙, 600$ 現象の計測を行った。 PIV 解 析は直接相互相関法を用い，相関領域を $50 \%$ オーバラップ
する条件で行った。騒音計測は, 半円柱, 円柱中心からの 距離 $r=0.5 \mathrm{~m}$ の位置にマイクロホン（測定範囲： 40-130dB (Flat 特性), 周波数範囲 : 20-8, 000Hz) を設置し て行った。 マイクロホンの周波数特性には, Flat 特性を使 用し, サンプリング間隔を $100 \mu \mathrm{sec}$, サンプリング時間を $2 \sec$ として, 30 回繰り返し計測を行った.

\subsection{POD 解析}

流れ場の特徵的な構造を抽出する方法の一つとして, POD 解析がある. 本研究では時間で離散化した瞬時速度場 から固有ベクトルを求める Snapshot POD を用いた ${ }^{(5),(6)}$. このSnapshot POD は, 各時刻の速度場に対して相関行列を 計算し, この相関行列から固有值, 固有ベクトルを算出す る. 次に得られた固有ベクトルから固有関数を求めること で流れ場の特徵的な構造を抽出した。 また, 固有值から各 モードの寄与率を求めた.

\section{3. 結果および考察}

\section{1 騒音特性}

円柱ならびに半円柱の空力騒音計測で得られたスペクト ル分布を Fig. 2 に示す. 半円柱では $f=402 \mathrm{~Hz}$, 円柱で は $f=370 \mathrm{~Hz}$ にそれぞれ騒音のピークが見られる.また， 半円柱の方が円柱よりも $10 \mathrm{~dB}$ 程度音圧レベルが低いこと がわかる。これらの騒音ピーク值の周波数から得られるス トローハル数 $S t\left(=f D / U_{0}\right)$ は, 半円柱では 0.2 , 円柱では 0.19 である ( $f$ : 周波数). なお, 円柱においてはカルマ ン渦の発振周波数から算出した過去の実験結果 ${ }^{(1)}$ とよく一 致する.

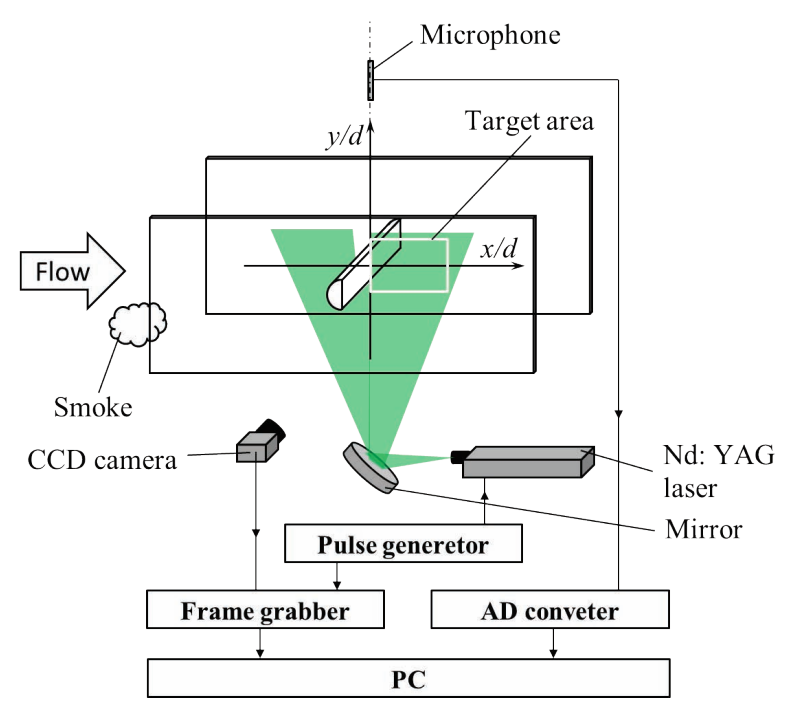

Fig.1 Experimental setup 


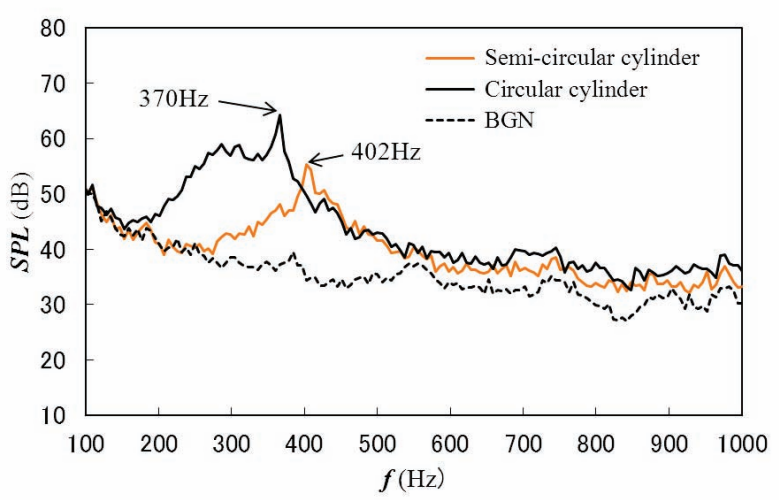

Fig. 2 Sound spectrum distributions

このことから，騒音のピーク值はカルマン渦の放出に伴い 発生する騒音であり，半円柱においても同様であると考え られる。

\section{2 半円柱, 円柱周りの POD 解析結果}

Fig. 3 は，半円柱および円柱後流の瞬時速度場 600 セッ トから求めた 0 次を含めた 2 次モードまでの合成速度の POD 固有関数分布である. 上段が円柱, 下段が半円柱の結 果を示し，図中にエネルギーの寄与率が記されている。こ の寄与率は, 1 次モードでは半円柱, 円柱共に $30 \%$ 以上占 めており，2 次モードでは若干小さくなるが 1 次モードと ほぼ同程度の寄与率であり，1 次と 2 次モードをあわせる と約 $60 \%$ の寄与率を占める。 また，半円柱では，円柱と同 様なエネルギーの寄与率が得られた。

時間平均速度場に対応する 0 次モードの解析結果による と, 半円柱と円柱の流れ場の違いは, 後流の逆流領域の広 がりに認められる。すなわち, 半円柱では, 両端から発す るはく離せん断層の厚さが下流方向に急激に増大し, 速度 勾配の低下を示唆する。このことは， $x / d=1$ 付近の断面内 速度分布に明瞭に認められる。一方, POD の 1 次と 2 次モ 一ドを見ると，半円柱の場合には，はく離せん断層付近で 速度変動の減少が認められ，０次モードの変化に対応した
変化が見られる。また, 半円柱の後流には, 円柱の場合と 同様の組織構造が形成されるが，これらの構造は上流側へ 移動する。このように半円柱後流には，はく離せん断層の 速度勾配の低下と速度変動の減少が発生するが，これらは 空力騒音特性の変化をもたらすことが期待される.一般に, 円柱の騒音の発生機構は, 流れのはく離点の変動ならびに はく離せん断層における渦の変動によって発生すると考え られている。本研究の POD 解析結果から得られたはく離 せん断層での速度変動の減少効果は, 空力騒音の発生原因 である渦変動の低下に直接対応する。このことは，半円柱 による空力騒音の低減メカニズムは，はく離せん断層の特 性の変化によることを示唆する. 一方, POD の 1 次と 2 次 モードに見られるように，半円柱では，円柱と類似の組織 構造が形成されるが，いずれのモードにおいても組織構造 の発生位置が上流側一移動しており, 発生する大規模渦の 周期が短いことがわかる。これは，カルマン渦の発生周波 数の増大に対応しており, Fig.2 の空力騒音のスペクトル 解析結果とも良く対応する。このように，半円柱後流の速 度場の POD 解析結果によると, はく離せん断層や後流の組 織構造が変化するため, 離散周波数騒音が低下寸ると考え られる。

\section{4. 結言}

本研究では, 半円柱周りの空力騒音の低減メカニズムの 解明を目的として，半円柱ならびに円柱から放出される騒 音の計測および速度場の評価を行った。その結果，半円柱 では, 音圧レベルの低下と渦発生周波数の増加が確認され た.

\section{参考文献}

(1) Fujita, H., Fluid Dyn. Res., 42(2010), 015002.

(2) Tomimatsu, S., Fujisawa, N., J. Vis, 5-4(2002), 381.

(3) Nashimoto, A., et al., J. Vis, 11-4 (2008), 365.

(4) Oguma,Y., et al., J. Wind Eng. Ind. Aerodyn, 118 (2013), 1.

(5) Zhou, X., Hitt, D. L., J.Turbulence, 5 (2004), 1.

(6) Oudheusden, B. W. Van., et al., Exp. Fluids, 39(2005), 86.

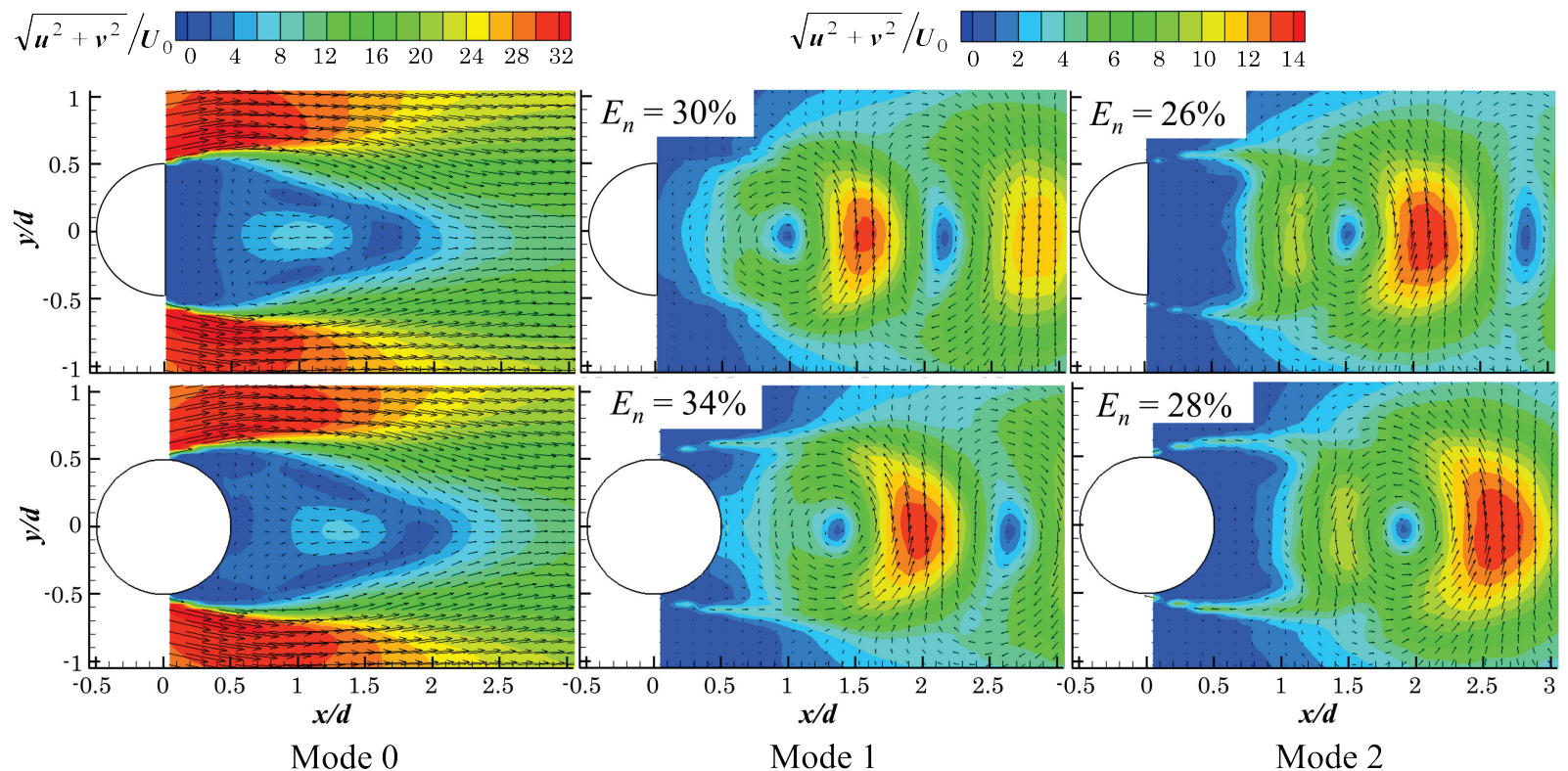

Fig. 3 Eigen-functions of velocity: top semi-circular cylinder, bottom circular cylinder. 